\title{
Integrating traditional knowledge when it appears to conflict with conservation: lessons from the discovery and protection of sitatunga in Ghana
}

\author{
$\underline{\text { Jana M. McPherson }}^{1}, \underline{\text { Joy Sammy }}^{1,2}, \underline{\text { Donna J. Sheppard }}^{1,2,3,4}, \underline{\text { John J. Mason }}^{3}$, Typhenn A. Brichieri-Colombi $^{1}$ and $^{\text {Axel }}$ \\ Moehrenschlager ${ }^{1}$
}

\begin{abstract}
Cultural traditions can conflict with modern conservation goals when they promote damage to fragile environments or the harvest of imperiled species. We explore whether and how traditional, culturally motivated species exploitation can nonetheless aid conservation by examining the recent "discovery" in Avu Lagoon, Ghana, of sitatunga (Tragelaphus spekii gratus), a species familiar to locals, but not previously scientifically recorded in Ghana and regionally assumed extinct. Specifically, we investigate what role traditional beliefs, allied hunting practices, and the associated traditional ecological knowledge have played in the species' discovery and subsequent community-based conservation; how they might influence future conservation outcomes; and how they may themselves be shaped by conservation efforts. Our study serves to exemplify the complexities, risks, and benefits associated with building conservation efforts around traditional ecological knowledge and beliefs. Complexities arise from localized variation in beliefs (with cultural significance of sitatunga much stronger in one village than others), progressive dilution of traditional worldviews by mainstream religions, and the context dependence, both culturally and geographically, of the reliability of traditional ecological knowledge. Among the benefits, we highlight (1) information on the distribution and habitat needs of species that can help to discover, rediscover, or manage imperiled taxa if appropriately paired with scientific data collection; and (2) enhanced sustainability of conservation efforts given the cultivation of mutual trust, respect, and understanding between researchers and local communities. In turn, conservation attention to traditional ecological knowledge and traditionally important species can help reinvigorate cultural diversity by promoting the persistence of traditional belief and knowledge systems alongside mainstream worldviews and religions.
\end{abstract}

Key Words: Anlo-Keta Lagoon Complex; community-based conservation; local knowledge; shrines; traditional beliefs; traditional ecological knowledge; traditional species harvest; Tragelaphus spekii gratus

\section{INTRODUCTION}

Meaningful integration of traditional ecological knowledge (TEK), practices, and beliefs in conservation projects has emerged as a significant determinant of conservation success (Brooks et al. 2012). Such integration seems intuitive when cultural traditions, i.e., knowledge, practices, and/or beliefs, align with conservation goals; for instance when traditional taboos restrict harvesting of an imperiled species (Riley 2010, Sheppard et al. 2010) or serve to create temporal or spatial wildlife sanctuaries (Johannes 2002, Bhagwat 2012). In contrast, it is less clear how cultural traditions might aid conservation when they conflict with conservation. In Portugal, for example, the nationally vulnerable Mediterranean house gecko (Hemidactylus turcicus) is persecuted because folklore links it with disease (Ceríaco et al. 2011); in Cambodia internationally endangered birds, such as yellowbreasted bunting (Emberiza aureola; http://www.iucnredlist.org/ details/22720966/0) are captured for merit release (Gilbert et al. 2012); and in Madagascar, near threatened (http://www. iucnredlist.org/details/6302/0) aye aye (Daubentonia madagascariensis) are killed because these lemurs are considered harbingers of death (Simons and Meyers 2001). However, the United Nations Convention on Biological Diversity includes goals regarding the protection of biodiversity and "traditional knowledge, innovations and practices" (UN 1992). Can the protection of biological and cultural diversity go hand in hand when traditional practices conflict with conservation needs?

We examine the interplay between tradition and conservation in a case study from West Africa. Specifically, we investigate how traditional ecological knowledge, practices, and beliefs in Avu Lagoon, Ghana, led to the "discovery" and subsequent protection of sitatunga (Tragelaphus spekii gratus). The species, locally familiar and known as "tsimese," has declined considerably in West Africa (http://www.iucnredlist.org/details/22050/0) and had never before been scientifically recorded within Ghana. Its former occurrence in the country had, however, been inferred from now vanished populations in the Oti River basin in neighbouring Togo, approximately $500 \mathrm{~km}$ north of Avu, which were last observed in 1952 (Adjewodah and Yerenkyi 1999). The sitatunga was therefore deemed extinct in Ghana (East 1990). The species is the world's only aquatic antelope. Elongated, widely splayed hooves allow it to walk on dense floating vegetation in wetland habitats. When startled, this largely nocturnal animal plunges underwater until only its nostrils are above the surface (Kingdon 1982), rendering detection difficult.

We explore: (1) what role the traditions associated with sitatunga hunting in Avu played in the scientific discovery of sitatunga and the resulting community protected area (CPA); (2) how these

${ }^{1}$ Centre for Conservation Research, Calgary Zoological Society, ${ }^{2}$ Protected Areas and Poverty Reduction Canada-Africa Learning Alliance, Vancouver Island University, ${ }^{3}$ Nature Conservation Research Centre, ${ }^{4}$ Rural Studies, School of Environmental Design and Rural Development, University of Guelph 
traditions may ultimately shape and be shaped by conservation outcomes; and (3) to what extent traditional knowledge on sitatunga suffices in understanding the species' local distribution. Our study highlights benefits, limitations, and complexities of integrating tradition and conservation when they appear in conflict and provides guidance on doing so.

\section{STUDY AREA}

Avu Lagoon in southeastern Ghana is used and owned by 15 communities totalling approximately 12,800 inhabitants in 2012 (projected on the basis of national census data from 2000; GSS 2005). Inhabitants primarily live off farming and fishing and are predominantly Ewe, an ethnic group that migrated to the area several centuries ago. Communities access the lagoon and surrounding seasonally flooded lands to farm sugarcane for gin production, to fish, hunt, and gather water, fuel wood, and materials for weaving. The area comprises a 277.67 hectare freshwater lagoon that is $11 \mathrm{~km}$ long, up to $5 \mathrm{~km}$ wide, and falls within the boundaries of the otherwise predominantly brackish 69,445.42 hectare Anlo-Keta Lagoon Complex (Fig. 1), which since 1992 has been recognized as a wetland of international importance under the RAMSAR Convention. Local environmental threats include pesticide run-off from farming, overexploitation of fisheries, bush burning, and commercial harvesting of firewood. Upstream damming of the Volta River in 1964 has altered drainage patterns, resulting in reduced seasonal flooding, siltation, and the blockage of channels (Willoughby et al. 2001).

Fig. 1. Map of Avu Lagoon settlements and the community protected area (CPA).

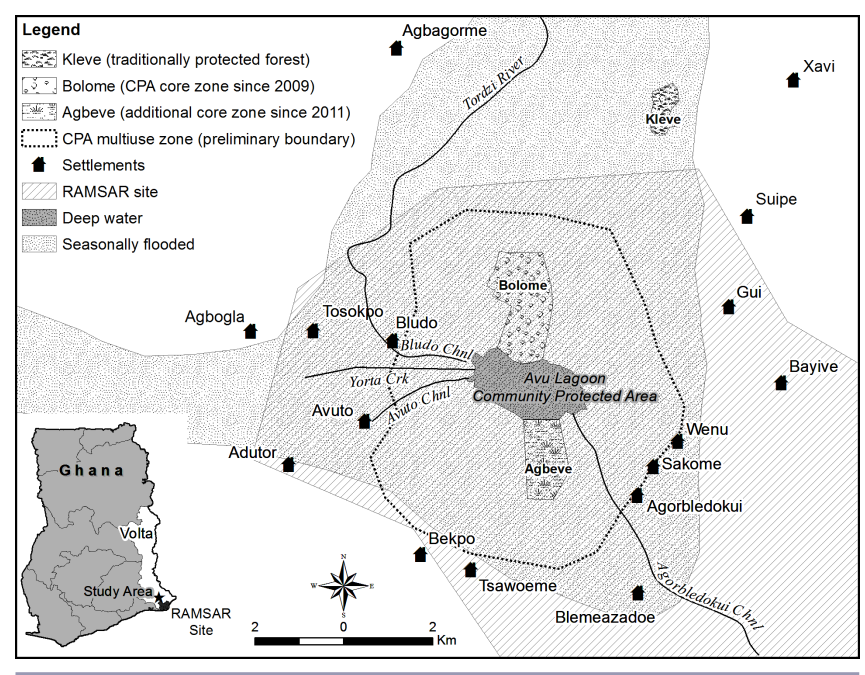

Avu residents, until recently, hunted sitatunga for its meat and hide, but also to fulfil traditional beliefs. Ewe traditional religion is polytheistic, with one supreme deity (Mawu) and many other divine beings associated with particular natural phenomena (e.g., rain, wildlife), places (e.g., rivers, the lagoon), communities, or family clans (Parrinder 1961). Adherence to traditional beliefs is rapidly fading across Ghana, with only $5 \%$ of the population selfidentifying as traditionalist in a 2010 census compared to $21 \%$ in 2000 (Golo and Yaro 2013). Locally, however, traditional beliefs still coexist alongside Christianity and are represented by a variety of physical shrines. Sitatunga horns and bones used to be deposited at such shrines to honor and thank traditional deities.

Motivated by the need to protect sitatunga and its habitat, but also with the hope of economic diversification, 15 communities surrounding Avu Lagoon, Ghana's Forestry Commission's Wildlife Division, and the Nature Conservation Research Centre (NCRC) jointly initiated a community protected area (CPA) in 2006. The Wildlife Division provided technical expertise. The NCRC, a Ghanaian nongovernmental organization, was crucial in accessing funding from IUCN Netherlands, which until 2010 supported research, education, and training for the development and management of the CPA. To attract ecotourism, a visitor centre and two wooden platforms for viewing sitatunga were constructed, plus boat tours and home stays are on offer, but visitor numbers and associated revenue have been limited to date (20-40 visitors annually). Without consistent funding, the CPA is currently maintained by the dedication of key individuals, with CPA executives meeting voluntarily. Recent, increased inclusion in an Accra-based tour operator's itineraries, plus external support for a planned tree nursery program may, however, improve revenues in the near future.

The CPA has a strictly protected core zone (422 ha) with prohibitions on all hunting, fishing, farming, construction, and firewood collection, and a wider multiuse zone (4124 ha), in which activities harmful to sitatunga and other endangered species or their habitat (e.g., use of chemical fertilizers in farming, dynamite in fishing) are forbidden (Fig. 1). A CPA management board, comprising 30 elected representatives, 2 per community, is responsible for disseminating and enforcing the relevant bylaws. The management board is assisted by a subcommittee in each community composed of 7-15 members drawn from community institutions, such as churches, women's, hunters', and cultural groups. Additionally, 10 local youths were trained by NCRC and the Ghana Wildlife Division as an environmental education team, which in 2008-2009 held 38 workshops to inform residents about the protected area, its wildlife, and environmentally friendly methods of farming and fishing (Appendix 1). The process is underway to have the CPA legally recognized as a community resource management area (CREMA) under Ghana's Wildlife Division policy for Collaborative Community-based Resource Management and the Wild Animals Preservation Act.

\section{METHODS}

Traditional ecological knowledge (TEK) is commonly defined as "a cumulative body of knowledge, practice, and belief, evolving by adaptive processes and handed down through generations by cultural transmission, about the relationship of living beings (including humans) with one another and with their environment" (Berkes et al. 2000:1252). Because the origin of some elements of knowledge can be hard to disentangle (Davis and Ruddle 2010), we use the term more broadly to also include contemporary local ecological knowledge (LEK) "based on the observations of individuals during their lifetimes" (Gilchrist et al. 2005). Where appropriate, however, we distinguish the various components that comprise TEK, including (1) information about ecosystem components, their dynamics, and inter-relationships (ecological know-how that likely blends passed-down knowledge, TEK, with 
Table 1. Summary of interviews conducted, indicating interview method, participants, and subject of enquiry. Participants were identified by peer selection (Huntington 2000), and all interviews were facilitated by a translator.

\begin{tabular}{|c|c|c|c|c|}
\hline Topic & Interview type & Method & Participants & Information sought \\
\hline $\begin{array}{l}\text { Traditional ecological knowledge's } \\
\text { contribution to species discovery, } \\
\text { community protected area (CPA) }\end{array}$ & $\begin{array}{l}\text { Eyewitness } \\
\text { interviews } 2012\end{array}$ & $\begin{array}{l}\text { semistructured } \\
\text { individual }\end{array}$ & $\begin{array}{l}\text { three persons involved in } \\
\text { the discovery, including } \\
\text { author JJM }\end{array}$ & $\begin{array}{l}\text { events leading to the discovery } \\
\text { of the sitatunga }\end{array}$ \\
\hline
\end{tabular}

initiation, and management

Board member interviews 2011

Traditional management practices, beliefs, and their dynamics
Elder focus groups 2012

\section{semistructured individual or in pairs (pairs of} representatives from the same community)

semistructured group interviews
Shrine caretaker interviews 2011-2012

Ecological know-how on sitatunga
Hunter Interviews $2006^{\dagger}$ semistructured individual uthor JJM

\begin{tabular}{|c|c|}
\hline $\begin{array}{l}28 \text { (of } 30 \text { ) members of } \\
\text { the CPA's governing } \\
\text { board: each community } \\
\text { in the CPA is } \\
\text { represented by } 1 \text { man } \\
\text { and } 1 \text { woman }\end{array}$ & $\begin{array}{l}\text { role of traditional leaders, } \\
\text { tradition, and culture in the } \\
\text { formation and management of } \\
\text { the CPA }\end{array}$ \\
\hline lders in five & beliefs, usage, and rituals \\
\hline Wenu (five people) & emphasis on ties to wildlife; \\
\hline Tosukpo (eight people) & changes in habitat, wildlife, and \\
\hline $\begin{array}{l}\text { Agorbledokui (six } \\
\text { people) Avuto (seven } \\
\text { people) }\end{array}$ & beliefs through time \\
\hline $\begin{array}{l}\text { leamazado (six } \\
\text { eople). }\end{array}$ & \\
\hline $\begin{array}{l}\text { riests and caretakers of } \\
\text { arines in forest groves }\end{array}$ & $\begin{array}{l}\text { purpose and history of shrine } \\
\text { and permission to examine its }\end{array}$ \\
\hline 2) and settlements (58) & $\begin{array}{l}\text { contents; size, habitat type, and } \\
\text { condition of sacred forest and } \\
\text { permission to visit }\end{array}$ \\
\hline $\begin{array}{l}7 \text { hunters from } 9 \\
\text { ommunities }\end{array}$ & $\begin{array}{l}\text { circumstances and location of } \\
\text { sitatunga sightings up to } 2006\end{array}$ \\
\hline
\end{tabular}

28 (of 30) members of

in the CPA is

represented by 1 man

communities:

Wenu (five people)

Agorbledokui (six

people) Avuto (seven

people)

people) shrines in forest grove permission to visit sitatunga sightings up to 2006

${ }^{\dagger}$ Hunter interviews were not repeated at a later date given the ban on sitatunga hunting since 2006.

personal observation, LEK); (2) practices regulating resource use (management know-how, primarily traditional in Avu, TEK); (3) social institutions that govern how humans interact with each other and with natural resources (social structure, traditional in Avu, TEK); and (4) the worldview and values within which all these are embedded (beliefs, transitioning between traditional religion and Christianity in Avu, TEK; Houde 2007).

We obtained background information on Avu Lagoon, the CPA, and local TEK from documents produced by NCRC. We then conducted individual and group interviews in Avu to gain further insights on (1) how various components of TEK contributed to the discovery of sitatunga and the formation and management of the CPA; (2) traditional management practices and beliefs and how they may interact with conservation outcomes; and (3) traditional ecological know-how on sitatunga (Table 1; Appendix 2). Interview formats varied depending on the type of information sought: informants with specialized knowledge, e.g., hunters, shrine caretakers, and board members, were interviewed individually to gain an in-depth understanding of their perspectives and practices. Group interviews contextualized information gathered from individuals and helped illuminate the common, negotiated understanding of cultural customs and beliefs. Overlap in the topics covered during interviews with different stakeholders allowed for both cross-validation and clarification (Meijaard et al. 2011, Parry and Peres 2015).

For additional insights on traditional management practices and their potential interaction with conservation, we conducted a survey of shrines and sacred groves in 2011-2012. Sacred groves, common in Ghana, are forested areas surrounding shrines or burial grounds (Ormsby 2012); because access is usually restricted, such areas often contain undisturbed habitat of potential conservation value (Bhagwat 2012). During the survey, we recorded the number and location of all accessible shrines within the 15 settlements and visited each sacred grove to map its area with a GPS and check for evidence of sitatunga presence.

Additional insights on traditional ecological know-how were gained via collaborative fieldwork (Huntington 2000): hunteraided surveys that gathered secondary evidence of the presence of sitatunga, e.g., footprints, track ways, feces, browsing signs, sleeping spots, and horn scratching posts. An initial 10-day baseline survey encompassing much of the wetland took place in 2006, during which the ecological know-how of local hunters was critical in identifying access routes, the best season and modes of travel, and areas known for sitatunga. Hunters indicated secondary signs of sitatunga and sites where within the last six months they, or bystanding locals, had sighted sitatunga, which we recorded using a handheld GPS. We undertook further, more opportunistic surveys of secondary evidence of sitatunga during the course of other fieldwork in 2006-2010, 2012, and 2013 (225 search hours in total; Fig. 2). Encounter rates, i.e., secondary signs, excluding reported recent sightings, per 10 hours of hunteraided survey effort in each year, served as a rough indicator of temporal trends in relative abundance. Because the timing of surveys varied and encounter rates might fluctuate seasonally 
Fig. 2. Spatio-temporal distribution of survey effort and encounters of sitatunga evidence during hunter-aided surveys and camera trapping (2006-2013).
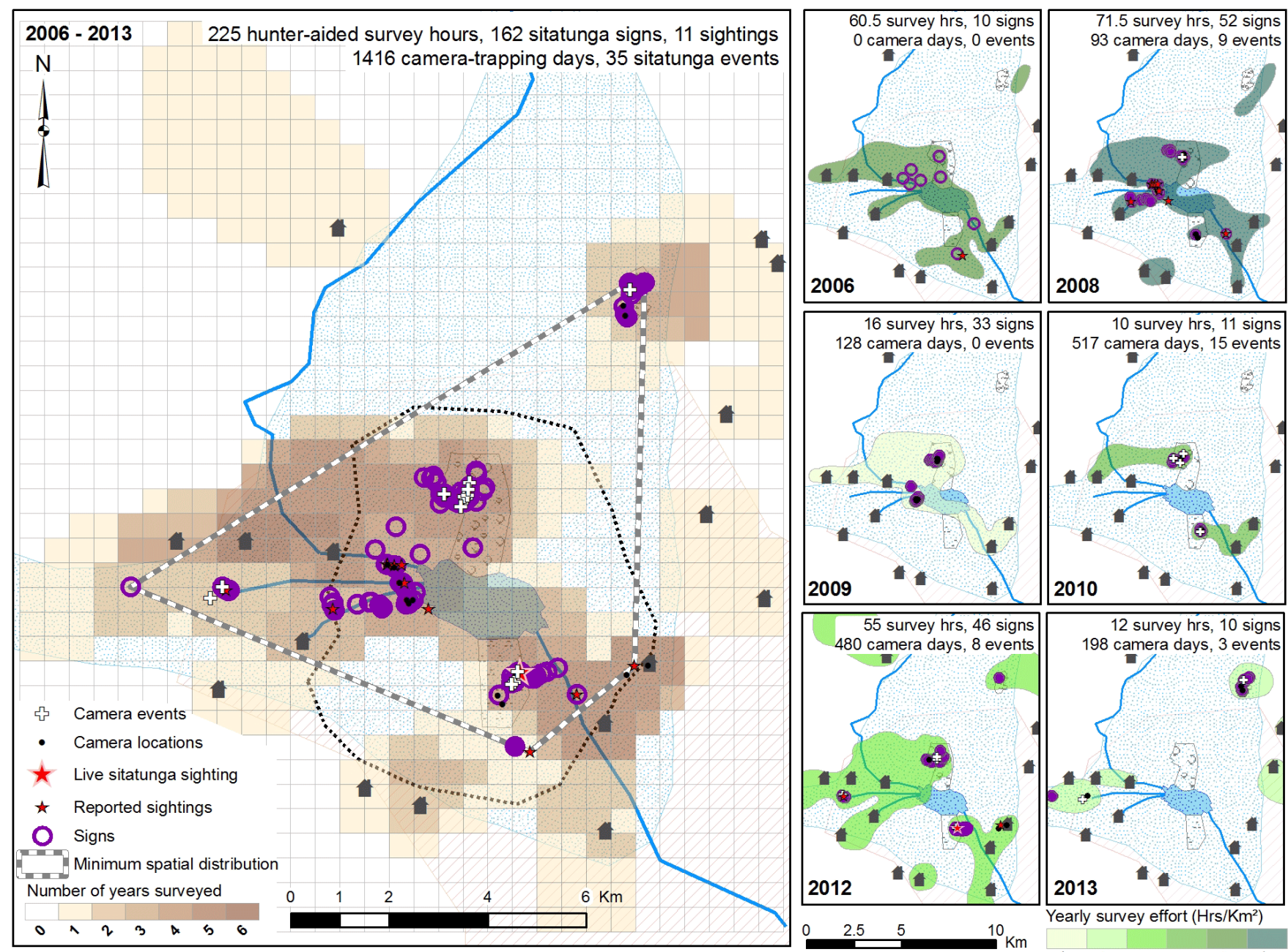

$0^{6} 0^{0^{2}} 0^{9} 0^{1} \eta^{10} \eta^{5}$

with inundation levels, we also computed encounter rates for specific months (March and May) during which we had data for most years. We also computed encounter rates for sleeping spots only, because unlike other secondary signs, these may be most indicative of the number of sitatunga individuals utilizing the habitat surveyed.

To corroborate traditional ecological know-how on sitatunga with a scientific approach, we deployed camera traps using a nonrandom sampling design directed at maximizing capture of rare and elusive species (Burton et al. 2011, Rowcliffe et al. 2013). Cameras (Reconyx/RM45 Rapidfire except in 2008 when we used Cuddeback/Excite) were placed in selected locations where hunters recalled recently seeing sitatunga or provided secondary evidence of its presence. Field crews composed of retrained former hunters set cameras initially in Bolome, Agbeve, and between the Bludo and Avuto channels (2008), then in Bolome and near the Avuto channel (2009), in Bolome and Agbeve (2010,
2012), Yorta and Wenu (2012), and Yorta and Kleve (2013; Table 2; Fig. 2). Wenu served as a control site, because no prior evidence of sitatunga was known from this swampy but human-frequented area. Images of sitatunga captured by the same camera were considered discrete events if separated by at least one hour. We used encounter rates, i.e., the average number of sitatunga events captured by each camera per 10 days of deployment in each year, as a rough indicator of abundance trends. To control for variation in camera locations from year to year, we also computed camera encounter rates separately for the two core areas, Bolome and Agbeve, for which we had camera-trap data in four and three years, respectively.

All research methods had ethics approval from the research ethics board of either the University of Guelph or Vancouver Island University. 
Table 2. Overview of the temporal and spatial distribution of sitatunga events captured by camera traps 2008-2013.

\begin{tabular}{|c|c|c|c|c|}
\hline Year & Location & Effort & $\begin{array}{l}\text { Total } \\
\text { sitatunga } \\
\text { events }\end{array}$ & $\begin{array}{l}\text { Sitatunga events } \\
\text { per camera }\end{array}$ \\
\hline \multirow[t]{4}{*}{2008} & Bolome & $\begin{array}{l}10 \text { days } \times 4 \\
\text { cameras }\end{array}$ & 9 & $\begin{array}{l}\text { Camera A: } 0 \\
\text { Camera B: } 0 \\
\text { Camera C: } 2 \\
\text { Camera D: } 7\end{array}$ \\
\hline & Bludo & 11 days $\times 3$ & 0 & Camera A: 0 \\
\hline & Channel & cameras & & $\begin{array}{l}\text { Camera B: } 0 \\
\text { Camera C: } 0\end{array}$ \\
\hline & Agbeve & $\begin{array}{l}10 \text { days } \times 2 \\
\text { cameras }\end{array}$ & 0 & $\begin{array}{l}\text { Camera A: } 0 \\
\text { Camera B: } 0\end{array}$ \\
\hline \multirow[t]{2}{*}{2009} & Bolome & $\begin{array}{l}43 \text { days } \times 2 \\
\text { cameras }\end{array}$ & 0 & $\begin{array}{l}\text { Camera A: } 0 \\
\text { Camera B: } 0\end{array}$ \\
\hline & $\begin{array}{l}\text { Avuto } \\
\text { Channel }\end{array}$ & $\begin{array}{l}42 \text { days } \times 2 \\
\text { cameras }\end{array}$ & 0 & $\begin{array}{l}\text { Camera A: } 0 \\
\text { Camera B: } 0\end{array}$ \\
\hline \multirow[t]{2}{*}{2010} & Bolome & $\begin{array}{l}65 \text { days } \times 5 \\
\text { cameras }\end{array}$ & 6 & $\begin{array}{l}\text { Camera A: } 4 \\
\text { Camera B: } 0 \\
\text { Camera C: } 0 \\
\text { Camera D: } 1 \\
\text { Camera E: } 1\end{array}$ \\
\hline & Agbeve & $\begin{array}{l}64 \text { days } \times 3 \\
\text { cameras }\end{array}$ & 8 & $\begin{array}{l}\text { Camera A: } 2 \\
\text { Camera B: } 0 \\
\text { Camera C: } 6\end{array}$ \\
\hline \multirow[t]{4}{*}{2012} & Bolome & $\begin{array}{l}48 \text { days } \times 4 \\
\text { cameras }\end{array}$ & 2 & $\begin{array}{l}\text { Camera A: } 1 \\
\text { Camera B: } 0 \\
\text { Camera C: } 0 \\
\text { Camera D: } 1\end{array}$ \\
\hline & Agbeve & $\begin{array}{l}48 \text { days } \times 3 \\
\text { cameras }\end{array}$ & 5 & $\begin{array}{l}\text { Camera A: } 5 \\
\text { Camera B: } 0 \\
\text { Camera C: } 0\end{array}$ \\
\hline & Yorta River & $\begin{array}{l}48 \text { days } \times 1 \\
\text { camera }\end{array}$ & 1 & Camera A: 1 \\
\hline & $\begin{array}{l}\text { Wenu } \\
\text { (control) }\end{array}$ & $\begin{array}{l}48 \text { days } \times 2 \\
\text { cameras }\end{array}$ & 0 & $\begin{array}{l}\text { Camera A: } 0 \\
\text { Camera B: } 0\end{array}$ \\
\hline \multirow[t]{2}{*}{2013} & Yorta River & $\begin{array}{l}48 \text { days } \times 2 \\
\text { cameras }\end{array}$ & 1 & $\begin{array}{l}\text { Camera A: } 1 \\
\text { Camera B: } 0\end{array}$ \\
\hline & Kleve & $\begin{array}{l}48 \text { days } \times 3 \\
\text { cameras }\end{array}$ & 2 & $\begin{array}{l}\text { Camera A: } 0 \\
\text { Camera B: } 0 \\
\text { Camera C: } 2\end{array}$ \\
\hline
\end{tabular}

\section{RESULTS}

Traditional ecological knowledge's contribution to species discovery and community protected area creation Interviews indicated that TEK and respectful engagement of TEK by scientists were important to species discovery and protection in three key ways. The first was respect for TEK: two of the three eyewitnesses interviewed recalled that the discovery of sitatunga was sparked when the Ghana Tourist Board's deputy director overheard rumours in a roadside eatery in the 1990s of a large cow-size animal killed in Avu Lagoon. Trusting in the ecological knowledge overheard, he engaged a local conservation scientist (JJM, coauthor on this publication) and a businessman native to Avu to follow up on the information. Out of respect for traditional social structure, contact with Avu communities was then initiated by approaching the area's traditional authorities, the chiefs of Avuto and Adutor, who facilitated introduction to local hunters. Hunters granted access to their hunting shrines once the visitors had provided for and joined in the pouring of libations, and eyewitnesses emphasized the importance that adherence to such local beliefs and practices played in building the trust that enabled information flow (Fig. 3).

Fig. 3. A hunter from Agorbledokui offering his collection of sitatunga trophies up for examination by scientists (including coauthor DJS) in 2006 once trust was established. These trophies are preserved in shrines or hunters' collections for years and thus are not indicative of recent hunting activity.

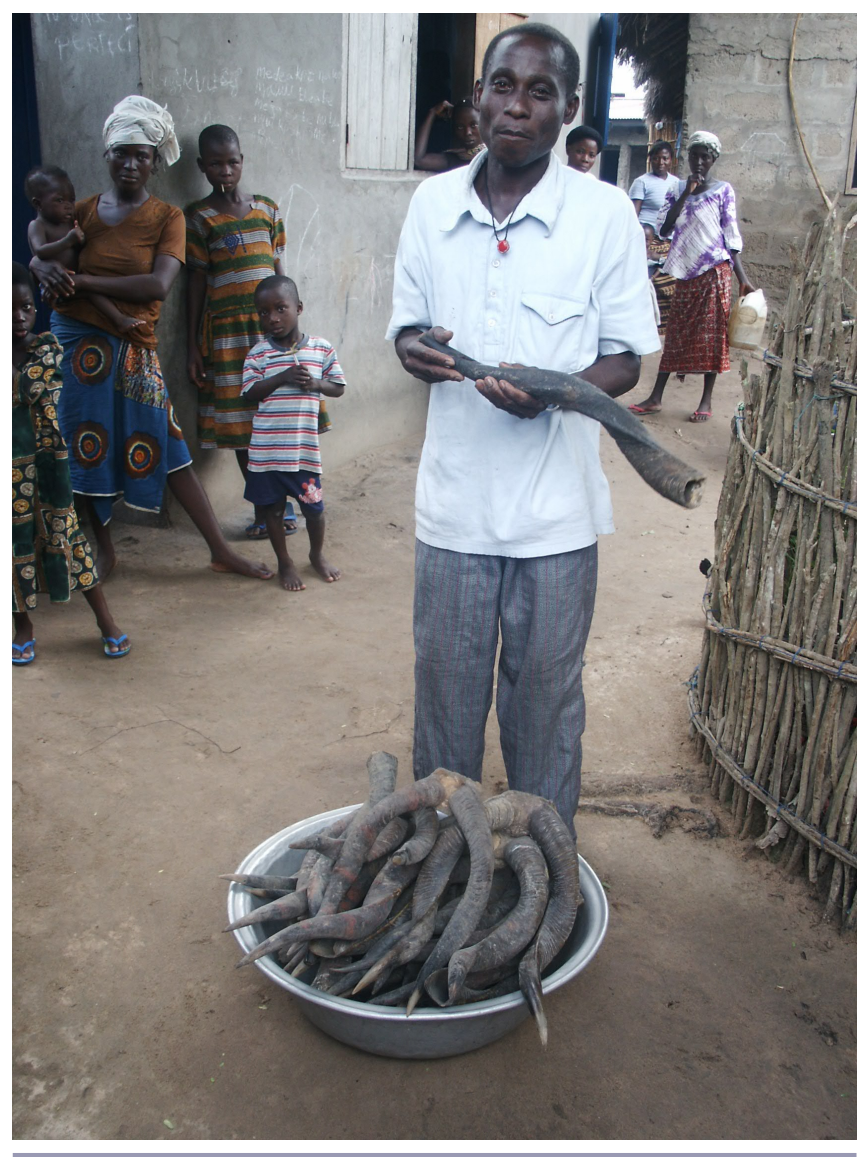

The second way was mutual exchange, validation, and integration of knowledge: inspection of several hunting shrines led to the recovery of two skins, a skull, two hooves, and three pairs of horns that JJM identified as sitatunga. Local hunters described these remains as the tsimese or water cow, and indicated where in the wetland the animals were often found; this information guided an aerial reconnaissance flight by the Ghana Wildlife Division in 1998, which spotted two males and one female sitatunga, resulting in Ghana's first scientific record for sitatunga. Learning of the species'special status sparked interest among Avu locals to protect the species and benefit from its rarity. Ultimately, this led to the formation of a CPA. 
The third way was integrating traditional social structure and ecological know-how in management: traditional authorities are considered ex officio members of the CPA's management board, and board member interviews revealed that, as land owners, traditional authorities necessarily engaged in and approved decisions regarding the allocation of land for protection. Moreover, chiefs and elders reportedly provide advice to and disseminate information from the board among the wider community. Hunters, too, have been important in shaping the CPA. Six current board members formerly hunted. Their and other hunters' ecological know-how on the local distribution of sitatunga was essential in identifying Bolome and Agbeve as areas of prime habitat to be designated as core zones. Hunters also continue to serve as guides to NCRC field staff, and over 15 hunters have been trained and deployed in camera-trapping teams.

\section{Insight into the dynamics of traditional management practices and beliefs}

Our survey of shrines and sacred groves identified 36 traditionally protected forests associated with 13 of the 15 communities in Avu. Only Agorbledokui and Tosukpo, two land-limited communities closely surrounded by inundated terrain, had no sacred forests. Caretakers and elders explained that, in addition to consulting forest shrines whenever needed, communities annually visit their forests in a predefined order during a ceremony, which culminates in butchering an animal at the last shrine visited for a community feast. Most forests were small ( 7 comprised individual trees; 22 others were $<0.5$ hectares), although caretakers' assessments differed because they based their measurement on the residing deity's strength rather than the forest's physical extent. Only one unusually large ( $\geq 42.03$ hectare) forest named Kleve yielded evidence of sitatunga (Fig. 2), and according to both the grove's caretaker and the chair of the CPA's management board, this discovery helped reinvigorate the forest's protected status, with notably less human encroachment in 2013 than 2012. Human encroachment (feces, rubbish, cut trees) was evident in 10 groves, including Kleve, and 2 further groves were severely degraded. Caretakers explained that waning interest and money from the community caused by increasing conversion to Christianity contributed to such neglect, but believed that divine forces would ultimately safeguard the forests. Accordingly, caretakers worried about human encroachment not because of habitat damage, but because it constituted a potential offence to the gods. Furthermore, each caretaker was only concerned about the fate of his own grove(s), indicating a lack of peer pressure regarding grove maintenance.

Our survey also identified 180 nonforest shrines that served a variety of purposes, including hunting, fishing, healing, fortune telling, and war. We focused on fishing and hunting shrines, given their potential relevance to sitatunga and its habitat.

Fishing shrines, of which we surveyed nine, are community shrines at which locals pour libations or leave offerings to encourage successful fishing. Elders in focus groups mentioned several traditional taboos associated with these shrines, including prohibitions on consuming certain fish species and weekly taboo days on which fishing is forbidden. In at least some communities, taboos are enforced via penalties, i.e., violators must provide the drink or animal sacrifice necessary to reappease the gods. More generally via traditional beliefs, i.e., violators can expect punishment from an offended ancestor or deity; these beliefs continue to be respected by some but not all converts to Christianity. Although elders indicated that taboos had always been broken to some degree, changing environmental conditions may have contributed to increasing neglect: all five focus groups suggested that the upstream Akosombo Dam had resulted in fewer fish and lower catches and had thus encouraged the breaking of taboo days. One focus group also suggested that poorer fish harvests had increased hunting pressure on other wildlife.

Hunting shrines, of which we surveyed 100, usually serve individual family clans. The name reflects the clan's descent from a hunter. According to caretakers, most shrines ( 58 of 64 for which we obtained information) were consulted primarily for hunting, but elders clarified that they can serve a variety of needs, including healing, fertility, and finance. Animal remains, such as bones or horns, are deposited at the shrine as a token of thanks after each successful hunt. Additionally, animals may be sacrificed there to thank or ask the deity for help on other occasions. Moreover, in the two communities without sacred forests, hunting shrines are central to the annual ritual involving the butchering of an animal for a community feast. Although few community members specialize in hunting, most take wildlife opportunistically while farming or fishing, and as the largest animal present, sitatunga was once a prized catch. Of the 64 hunting shrines examined, 11 contained animal remains; 5 included evidence of wild animals, i.e., 3 sitatunga, 1 African civet (Civettictis civetta), and 1 genet; 4 contained domestic animal remains; and 2 contained remains of unknown origin.

Elder focus groups explained that animal remains deposited at shrines usually include only bones, horns, or other parts that are not otherwise used and that in general any animal can appease the gods. The preference is for larger gifts, i.e., larger animals. According to two focus groups, use of sitatunga at shrines had therefore always been opportunistic; sitatunga were not specifically sought out but used when available because they are the largest wildlife species available. Four focus groups mentioned that for the annual ritual, their communities had used domestic animals for generations. In Tosukpo, elders indicated that sitatunga had formerly been the preferred sacrifice during annual rituals, but also suggested that the species acquired this special status only once other, larger wildlife vanished. Tosukpo elders stated: "The bigger the size of the animal, the better the gift. The best gift used to be the hippo but when the hippo finished, the next biggest is the sitatunga." With the notable exception of elders in Agorbledokui, respondents therefore implied that sitatunga bore no special significance within traditional beliefs, and respondents consequently did not think that the CPA and the associated ban on hunting sitatunga had a negative impact on shrines. According to three focus groups, shrines instead faced bigger threats from Christianity, because converts do not contribute to and in some cases actively oppose the upkeep of shrines and related ceremonies.

In Agorbledokui, in contrast, elders considered sitatunga essential for the annual ritual honoring the hunting shrines of three predominant clans in the community: "To our people the only thing to appease the gods is the sitatunga; even if we use a 
Table 3. Summary of secondary evidence of sitatunga gathered during hunter-aided surveys 2006-2013.

\begin{tabular}{|c|c|c|c|c|c|c|c|c|c|}
\hline$\overline{\text { Year }}$ & $\begin{array}{c}\text { Effort } \\
\text { (hours) }\end{array}$ & $\begin{array}{c}\text { Tracks and track } \\
\text { ways }\end{array}$ & $\begin{array}{c}\text { Crossing } \\
\text { points }\end{array}$ & Feces & Sleeping spots & $\begin{array}{c}\text { Feeding } \\
\text { signs }\end{array}$ & $\begin{array}{c}\text { Horn } \\
\text { rubbing }\end{array}$ & Live sighting & Recent sighting $^{\dagger}$ \\
\hline 2006 & 60.5 & 3 & 3 & 2 & 2 & 0 & 0 & 0 & 1 \\
\hline 2008 & 71.5 & 36 & 1 & 3 & 4 & 8 & 0 & 0 & 8 \\
\hline 2009 & 16 & 25 & 1 & 0 & 1 & 4 & 2 & 0 & 0 \\
\hline 2010 & 10 & 6 & 0 & 1 & 2 & 2 & 0 & 0 & 0 \\
\hline 2012 & 55 & 35 & 0 & 2 & 4 & 4 & 1 & 1 & 1 \\
\hline 2013 & 12 & 10 & 0 & 0 & 0 & 0 & 0 & 0 & 0 \\
\hline Total & 225 & 115 & 5 & 8 & 13 & 18 & 3 & 1 & 11 \\
\hline
\end{tabular}

Recent sightings refer to locations in which locals recollected seeing an animal within the preceding six months.

cow, the gods are not happy." In the elders' views, the prohibition on hunting sitatunga had therefore had an impact on traditional practices and well-being in this community: "Now we are suffering for our daily bread because the gods are not happy with us. We are facing hard times." Accordingly, the community has asked the CPA management board for an exemption from the hunting ban on sitatunga for the once-annual ritual hunt, but has so far been refused.

Whether this discontentment has led to breaches of CPA bylaws remains uncertain. Several informants have hinted at the occurrence of clandestine hunting excursions in which illegally caught game is butchered and cooked on site rather than brought home raw, reducing the likelihood of detection. We have not, however, been able to verify whether such undertakings have indeed occurred in the CPA core zone nor which species were targeted.

\section{Traditional ecological know-how}

Informal questioning of Avu residents during the peer-selection process indicated that, although few had actually encountered live sitatunga, all knew of sitatunga, most could describe its characteristic browsing damage to crops, and many knew from local narratives that female sitatunga will cache their young while foraging in waterlogged terrain.

During hunter interviews, some hunters recollected encounters with sitatunga as far back as 1994, but accounts predating 2004 were few (nine in total) and recounted in variable detail. We therefore report on sightings that occurred between 2004 and 2006 only. Hunters initially gave the impression that sitatunga sightings were frequent, but on average each hunter recalled only two sightings between 2004 and 2006, and four hunters recalled none. The highest number of sightings reported by a single hunter was five. In total, hunters recalled 35 sightings between 2004 and 2006: 21 male, 12 female, 1 juvenile, and 1 unknown. Nine sightings had occurred in or near Avu's deep-water body, six around Agorbledokui, six in or near Agbeve, five between Agorbledokui and Gui, five in Bolome, three in Bludo channel, and one in the Avuto channel.

Hunter-aided surveys recorded 173 incidences of secondary evidence for the presence of sitatunga (Table 3), and in March 2012 yielded one live sighting of a male sitatunga (Fig. 2). Most incidences occurred within the CPA's core (Bolome 53, Agbeve 21) or multiuse zones (79), but 20 fell outside these areas (Fig. 2). Spatial patterns in secondary evidence were somewhat reflective of search effort, with clustered observations near access channels and the location of other fieldwork (Fig. 2). A convex polygon connecting the outermost locations of recorded sitatunga signs suggests a minimum spatial distribution of 5143.2 hectares of favorable habitat interspersed with settlements (Fig. 2). Temporal trends are confounded by variation in the duration, location, area coverage, and season of surveys and so can provide only a very coarse indication of trends. All four abundance indicators we extracted from hunter-aided survey data, however, are suggestive of an initial increase after implementation of the hunting ban in 2006, with peak abundance in 2009-2010 and a subsequent reduction to levels below peak but still well above 2006 levels (Fig. 4).

Fig. 4. Temporal trends in encounter rates during (a) hunteraided surveys and (b) camera trapping conducted between 2006 and 2013.

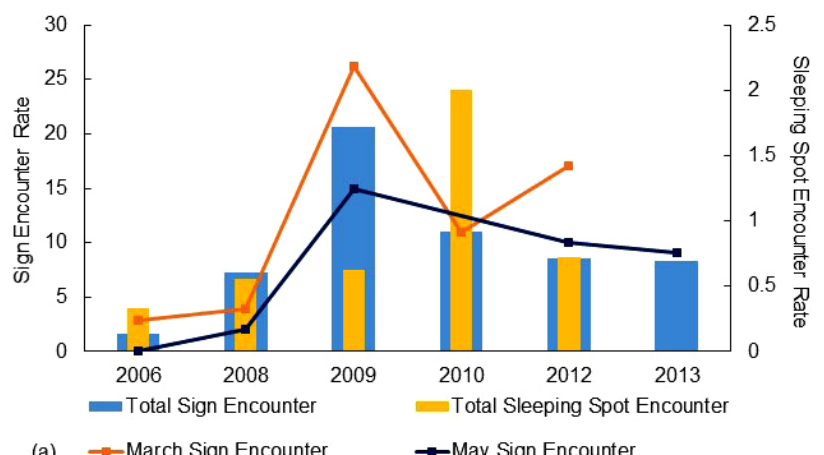

(a) -March Sign Encounter $\quad \rightarrow$ May Sign Encounter

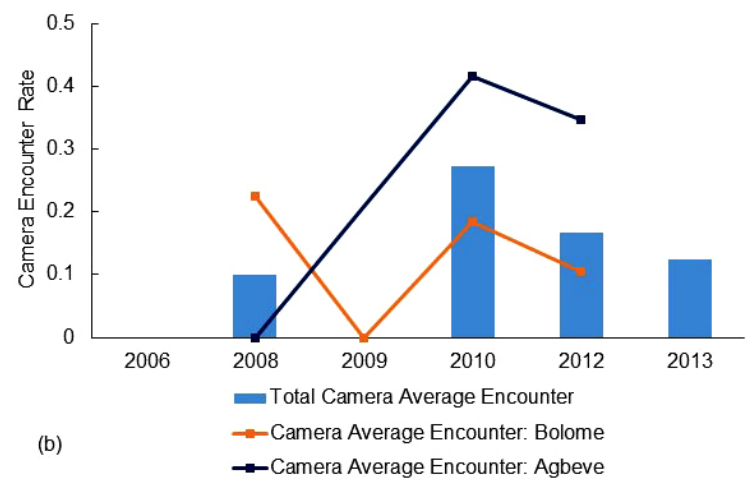




\section{Corroborating traditional ecological know-how with camera-trap data}

Camera traps confirmed the presence of sitatunga in all areas sampled in which TEK from hunter interviews and hunter-guided surveys had suggested sitatunga presence. Additionally, camera traps captured images of sitatunga in Kleve, where secondary signs of sitatunga had previously been encountered during the survey of shrines and sacred groves. At the control site, Wenu, no sitatunga were captured on camera (Table 2; Fig. 2). In total, camera traps captured 34 sitatunga events; 22 involved mature males, 8 young males, and 4 females. On a per-effort basis, events were most frequent in Agbeve (designated as additional core zone in 2011: 0.29 events on average per camera per 10 camera days), followed by Bolome (original core zone designated in 2009: 0.14), Kleve (0.14), which has seasonally submerged terrain similar to Bolome, and Yorta (0.14), which like Agbeve is permanently wet and comprises a small lagoon. No sitatunga events were caught on camera along the Avuto and Bludo channels, despite nearby secondary signs. Because the cameras provided no evidence that alternative antelope species were present, we in no way interpreted this as indicative of hunters misidentifying secondary signs. Moreover, subtle differences in camera placement, e.g., cameras positioned on same tree but facing in opposite directions, sometimes resulted in one camera capturing events while an adjacent one did not.

\section{DISCUSSION}

Counterintuitively, insights from the discovery of sitatunga in Avu suggest that traditions in seeming conflict with conservation, such as harvests of imperiled wildlife, can actually aid species protection. They can contribute to the long-term survival of imperiled wildlife if they yield physical evidence of species persistence, provide culturally rooted motivations for its preservation, or maintain skills useful in monitoring its status, distribution, and ecological needs.

In our case study from Avu Lagoon, a species was discovered by scientists because tradition encouraged its continued exploitation and the deposition of bones and horns at religious shrines. In one village, traditional beliefs specifically identified the species as the only appropriate offering to clan gods; elsewhere, tradition simply encouraged deposition of the largest possible offering, which happened to be sitatunga. Either practice resulted in physical evidence of sitatunga within shrines, without which officials might have discounted rumours of the cow-sized antelope; locals in Avu might not have come to realize the wider significance of sitatunga; and the community protected area now in place to safeguard the species might not have come to be.

Exploitation not only yields physical evidence, but also knowledge. Although such knowledge can hurt endangered wildlife when abused to indiscriminately satisfy commercial demand (Davis and Ruddle 2010), hunters and fishers have facilitated the discovery or rediscovery of rare species in several instances (Jiménez 1996, Rabinowitz et al. 1999, Serra et al. 2004). In Avu, hunters' ecological know-how about sitatunga has proven invaluable. It informed initial reconnaissance flights, which confirmed the species' presence, and helped traditional landowners delineate prime habitat as a strictly protected core zone. Hunters' abilities to spot secondary evidence of sitatunga has been key in mapping the species' local distribution, with hunter-aided surveys yielding considerably more data per effort than camera traps (data points/hour of effort: 174/225 $=0.773$ versus $34 / 34,848=0.001$, respectively). Other authors have similarly found that the efficiency of hunter-led surveys often exceeds that of more conventional survey techniques (Parry and Peres 2015).

Not all TEK will lead to new scientific discovery, of course, nor is hunters' ecological know-how or its transmission to scientists infallible (Huntington 2000, Foale 2006). Avu hunters, for example, never suggested searching for sitatunga in Kleve; evidence of sitatunga there was encountered unexpectedly during other fieldwork. In hindsight, it appears that hunters knew about sitatunga frequenting Kleve; it is unlikely that they purposefully withheld this information, e.g., to prevent CPA regulations being applied there, because use of the area is traditionally restricted anyhow. That they had not alerted researchers to Kleve in seven years of interaction may instead reflect one (or a combination) of two phenomena. First, informants in the community to which Kleve belongs may have considered the area too inaccessible, especially for visitors, and hunters, who all reside elsewhere, may not have felt entitled to speak of another community's land. Traditional ecological knowledge is generally most accurate for frequently visited areas and may lose relevance beyond the local context (Moller et al. 2004, Gilchrist et al. 2005, Foale 2006). Second, locals' alternative worldview may have contributed to the lack of mention. A healing village near Kleve is visited by those possessed by evil spirits or otherwise suffering spiritual afflictions. The stigma associated with that site may have rendered informants reluctant to reference the area. More generally, locals' worldview may lead them to judge the significance of information by different standards. The fact that caretakers base their assessment of the size of sacred forests on the residing deity's strength rather than physical dimensions is illustrative of this phenomenon and the degree to which local insight can get lost in translation (Davis and Ruddle 2010). This is a potential limitation to many forms of TEK, best overcome when detailed information on the local worldview is available. Gathering such information can aid crosscultural communication and intergenerational transfer of traditional knowledge systems (Walsh et al. 2013), but often requires much time and trust.

Another limitation to TEK may be people's varying capacity to track change. Local knowledge, whether traditional or contemporary, is often formed by casual observation of patterns in recurring events. During times of change, patterns may become too irregular to be recognizable, leaving TEK uncertain or outdated. A possible example from Avu was the suggestion during hunter interviews that sitatunga sightings were frequent, when in fact hunters on average recalled less than one sighting annually in recent years. This disconnect might reflect that hunters initially did not distinguish between seeing the animal (rare) versus seeing its tracks (common), but could also indicate that sitatunga in Avu used to be more abundant and sightings more frequent, and that hunters had not yet internalized this change. Previous studies indicate that TEK is better at capturing dramatic change or extreme events than gradually shifting averages (Moller et al. 2004, Gilchrist et al. 2005).

Poor systems for tracking change also leave TEK susceptible to the syndrome of shifting baselines (Drew 2005, Turvey et al. 2010, 
Pellier et al. 2014), whereby each generation adopts their own, or at best their mentors', earliest experience as the norm without realizing the extent of longer-term change (Pauly 1995). In Avu, traditional practice appears vulnerable to a slippery slope of shifting baselines, with offerings at shrines already reported to have moved from larger to smaller wildlife (hippopotamus to sitatunga) or away from wildlife altogether.

From a conservation perspective, such flexibility in tradition is a mixed blessing. On the upside, the fact that traditions are not static but continuously evolve (Andriamarovololona and Jones 2012) provides opportunities for conservation to influence traditional value systems. In Avu, the perceived value of sitatunga has clearly changed. In the words of a CPA board member from Adutor: "We used to hunt [sitatunga] for the meat to chop [eat] and sell. Two or three people will be rich, sell skin for shoemaker, and to form drums. Horns for decoration or for the shrines of the hunters. Used to keep the skull at the shrine. Now prefer to have the animal alive, there used to be plenty but now so few, a generation will come and see nothing." At the community level, this transition in values was attributed to species scarcity plus an educational campaign delivered by local youth. Such educational campaigns can be important in helping locals understand why a resource they cherish is at risk, and how the risks can be mitigated (Gilchrist et al. 2005). At the individual level, the redeployment of hunters as camera trappers aided the transformation of values among those who might otherwise be most opposed. Their involvement in research activities has acted as a form of conflict resolution by providing an alternative livelihood option while maintaining a connection to the animal that previously helped define their identity. Similar redeployments have aided conservation elsewhere (Drew 2005).

The downside of flexible traditions is that attachment to specific species may be weak, reducing the potential for tradition to act as a motivator for conservation. Although not all traditional harvesting systems ensure sustainability (Berkes et al. 2000), communities can become motivated to protect a resource when its depletion would impact long-held traditions or cultural identity (Garibaldi and Turner 2004, Dollo et al. 2010, Mcivor and Pungetti 2012). Such culturally rooted incentives to protect species may be more enduring than a conservation ethic imposed by external stakeholders. This may be particularly true when externally instilled conservation values are intertwined with utilitarian expectations, such as economic benefits from ecotourism, which may be slow to materialize (Sheppard et al. 2010).

In Avu, the insistence in Agorbledokui that sitatunga are needed for annual shrine rituals may, therefore, be a blessing in disguise. In the immediate term, it may pose challenges with regards to community cohesion and adherence to CPA bylaws. In the longer term, however, the religious importance of sitatunga to residents of Agorbledokui could help sustain efforts to protect the species when hopes of associated economic benefits fade or external project support dwindles. The community is clearly willing to compromise; hunters from Agorbledokui, as key members of the camera-trapping team, are critical to continued monitoring of sitatunga, and the community requested an exemption from the sitatunga hunting ban only for the annual ritual, not year-round.
It will be important, therefore, to engage the community's hunters and elders in discussions over how to ensure a supply of sacrificial animals long into the future. The current ban on hunting sitatunga may be culturally acceptable if seen as a temporary measure to ensure future, sustainable exploitation (cf. Mcivor and Pungetti 2012).

Sustainably harvesting species for traditional purposes is an obvious way to overcome potential conflict between preserving culture and species (Huntington 2000). Even minimal harvests can help reaffirm traditional rights, permit intergenerational transfer of knowledge and skills, and allow communities to reinvigorate traditional bonds with and TEK about particular species (Gaze and Smith 2009). Reinvigorated TEK then ideally allows those with customary ties to a species to contribute to managing the resource, creating locally motivated harvesting regulations that foster adherence (Huntington 2000, Gaze and Smith 2009, Dollo et al. 2010).

Discussions over the potential for a sustainable harvest in Avu will need to explore threats that are already partially recognized in local TEK, plus raise awareness over additional risks, including risks beyond the community's control, such as climate change and the apparent isolation of this sitatunga population from any other. On the upside, observations of immature sitatunga in cameratrap data and anecdotal accounts (in 2003 and 2008) of cached young indicate that local individuals are reproducing successfully. Moreover, the story of this discovery plus the unexpected encounter of sitatunga in Kleve raises hopes that the species remains to be discovered in other inaccessible parts of the wider region. Our coarse estimates of trends in relative abundance suggest that the sitatunga population responded positively to imposition of the hunting ban in 2006, with encounter rates increasing over the first three to four years. Reduced encounter rates after 2010, which nonetheless are well above 2006 levels, could reflect fluctuations around carrying capacity or dispersal from core, refuge habitat into a wider area, although we cannot exclude the possibility of limited, clandestine hunting. Determining whether and how a legal sustainable harvest can be achieved will require much additional data on abundance, population structure, and effective population size, plus methods to effectively monitor these parameters going forward. Regular, systematic hunter-aided surveys in conjunction with more extensive camera trapping that proportionally samples all habitat types in the area, for example, would help in estimating and tracking trends in the size of the sitatunga population (Burton et al. 2011, Rowcliffe et al. 2013).

The TEK of many resource-dependent societies includes indicators of resource status (Moller et al. 2004). In Avu, management-oriented TEK appears weak (e.g., apparent lack of peer pressure among caretakers of forest groves), or at least waning given diminishing relevance of traditional taboos to Christian converts, but traditional ecological know-how that served other functions in the past can often be repurposed for conservation (Drew 2005). Thus Avu hunters' abilities to read secondary evidence of sitatunga might yet contribute to population monitoring if combined with a scientifically informed spatio-temporal search schedule. 
Continued collaborative involvement of locals and their TEK in data collection and monitoring strengthens mutual understanding, respect, and trust between scientists and community members (Huntington 2000, Drew 2005, Gaze and Smith 2009), which is particularly crucial when the target of conservation is sacred or otherwise intertwined in local belief systems (Pungetti 2012). Only as trust builds are researchers likely to gain access to such potentially valuable information as the location of sacred areas and wildlife remains in shrines.

Shrines and rituals involving bones exist on all inhabited continents (McNiven and Feldman 2003, Äikäs et al. 2009, Kideghesho 2009) and can provide valuable information about species' current or historical distributions (Ferguson and Messier 1997, Turvey et al. 2014, 2015) and trends in abundance (Brown and Emery 2008, Turvey et al. 2013). Similarly, traditionally protected areas akin to Kleve, which remain relatively undisturbed and may harbor rare or endangered species, are widespread throughout the world (Bhagwat 2012). Increased attention to such culturally significant sites from the conservation community could prove mutually beneficial by providing new impetus for their protection and by reinvigorating traditional values more generally (Garibaldi and Turner 2004). In Avu, traditional protection of Kleve has been reinvigorated thanks to the recently adopted conservation ethic for sitatunga. Elsewhere in Ghana, external, conservation-motivated support for traditional taboos against harming monkeys (Colobus vellerosus and Cercopithecus mona lowei) has allowed Christian converts to re-embrace traditional values without a conflict of conscience and has led to an increase in the percentage of locals who openly identify themselves as traditionalists (Sammy 2010). Conservation attention to culturally significant sites and species elsewhere might likewise help mitigate the dilution of local TEK resulting from emigration, immigration, economic need, modern education, and conflict with other faiths (Andriamarovololona 2012).

\section{CONCLUSION}

In conclusion, we suggest that even traditions that seemingly conflict with conservation because they adversely affect imperiled species can be beneficial to conservation for two reasons: (1) the associated local ecological know-how can provide highly valuable information on species' presence and local distribution (Drew 2005, Foale 2006, Houde 2007, Turvey et al. 2014, 2015), as was evident for sitatunga; and (2) allied cultural connections to the species or its ecosystem can provide motivations for conservation stewardship (Garibaldi and Turner 2004), which may outlast alternative ethical or utilitarian incentives, although how this plays out at Avu remains to be seen.

On both fronts, there are caveats. As our study illustrates, the ecological know-how associated with traditional harvests can have limitations that should be considered when such knowledge is mobilized for conservation applications. Although intergenerational transmission of TEK has the potential to provide long-term ecological perspectives and much needed historical reference points for management (Moller et al. 2004), harvesters could be oblivious to gradual changes or affected by shifting baselines. This risk must be considered especially when environmental change (e.g., an upstream dam) or cultural shifts (e.g., in religious orientation) may have altered harvesters' interactions with the target species. Moreover, the ecological know-how locals share is likely context dependent both geographically and culturally (Turvey et al. 2014). It is thus best combined with scientific data collection that corroborates local knowledge and puts it into broader contexts (Gilchrist et al. 2005). If done in collaboration with locals, akin to hunter-aided surveys and camera trapping in Avu, such data collection provides opportunities to build mutual trust and respect (Gratani et al. 2011) and can instill local communities with a sense of pride, ownership, and financial benefit in the conservation effort (Drew 2005, Parry and Peres 2015). The resulting local motivation for conservation may be the most valuable outcome of engaging in the process of incorporating TEK in conservation management (Fig. 5) and may explain why such integration appears key to the success of community-based conservation projects (Brooks et al. 2012).

Fig. 5. Illustration of the conservation benefits generated when researchers collaboratively engage traditional ecological knowledge. Meaningful participation of locals and their knowledge in the data collection and decision-making processes surrounding species discovery and monitoring fosters mutual trust, local pride, and the necessary hands-on understanding that then translates into locally motivated conservation management.

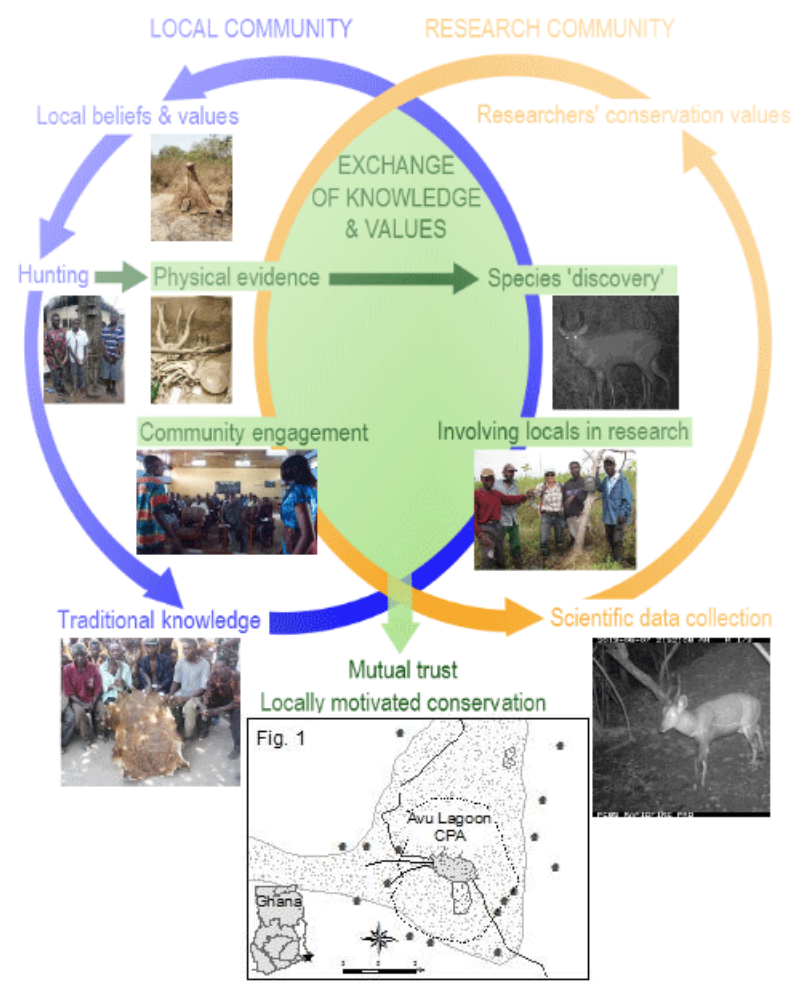

An obvious caveat with regard to cultural connections may be a community's insistence on harvesting imperiled species for cultural needs, even when this cannot be achieved sustainably. The important thing to remember, in such cases, is that traditional beliefs and practices are neither uniform nor static, as illustrated in Avu by differing opinions on the importance of sitatunga for shrine rituals, and by the abandonment of taboo fishing days in 
response to declining yield. Moreover, traditions can also be multifaceted, encompassing both potentially harmful practices, such as hunting, and beneficial practices, such as establishing sacred groves. This complexity provides opportunities for conservation to engage with traditional values when points of commonality can be found. The very process of engaging TEK facilitates the discovery of such commonalities, fostering strategic alliances between culture and conservation, which may ultimately prevent species extinctions, or at least buy time by reducing local threats while means to mitigate broader-scale threats are being determined.

Responses to this article can be read online at: http://www.ecologyandsociety.org/issues/responses. php/8089

\begin{abstract}
Acknowledgments:
We thank the communities of Avu Lagoon for their assistance, especially board members of the CPA and Nkuale $R$. W. We also thank all interviewees, $M$. Dome for assistance in the field, and $P$. Seddon, D. Reid, and several anonymous reviewers for valuable comments on earlier drafts. This research was supported by the Ghana Wildlife Division, NCRC, Calgary Zoo, the Protected Areas and Poverty Reduction Canada-Africa Learning Alliance of Vancouver Island University, and the Government of Alberta's Community Spirit Program.
\end{abstract}

\section{LITERATURE CITED}

Adjewodah, P., and G. Yerenkyi. 1999. Re-discovery of Sitatunga and Korrigum. IUCN Antelope Specialists Group Gnusletter IUCN Species Survival Commission, Peterborough, New Hampshire, USA. [online] URL: http://cmsdata.iucn.org/ downloads/vol 18 n1 1999 all.pdf

Äikäs, T., A.-K. Puputti, M. Núñez, J. Aspi, and J. Okkonen. 2009. Sacred and profane livelihood: animal bones from Sieidi sites in Northern Finland. Norwegian Archaeological Review 42 (2):109-122. http://dx.doi.org/10.1080/00293650903289641

Andriamarovololona, M. M., and J. P. G. Jones. 2012. The role of taboos an traditional beliefs in aquatic conservation in Madagascar. Pages 207-218 in G. Pungetti, G. Oviedo, and D. Hooke, editors. Sacred species and sites: advances in biocultural conservation. Cambridge University Press, Cambridge, UK. http://dx.doi.org/10.1017/cbo9781139030717.021

Berkes, F., J. Colding, and C. Folke. 2000. Rediscovery of traditional ecological knowledge as adaptive management. Ecological Applications 10:1251-1262. http://dx.doi.org/10.1890/1051-0761 (2000)010[1251:ROTEKA]2.0.CO;2

Bhagwat, S. A. 2012. Sacred groves and biodiversity conservation: a case study from the Western Ghats, India. Pages 322-334 in G. Pungetti, G. Oviedo, and D. Hooke, editors. Sacred species and sites: advances in biocultural conservation. Cambridge University Press, Cambridge, UK. http://dx.doi.org/10.1017/cbo9781139030717.031

Brooks, J. S., K. A. Waylen, and M. Borgerhoff Mulder. 2012. How national context, project design, and local community characteristics influence success in community-based conservation projects. Proceedings of the National Academy of Sciences 109 (52):21265-21270. http://dx.doi.org/10.1073/pnas. 1207141110

Brown, L. A., and K. F. Emery. 2008. Negotiations with the animate forest: hunting shrines in the Guatemalan Highlands. Journal of Archaeological Method and Theory 15:300-337. http:// dx.doi.org/10.1007/s10816-008-9055-7

Burton, A. C., M. K. Sam, D. G. Kpelle, C. Balangtaa, E. B. Buedi, and J. S. Brashares. 2011. Evaluating persistence and its predictors in a West African carnivore community. Biological Conservation 144(9):2344-2353. http://dx.doi.org/10.1016/j.

biocon.2011.06.014

Ceríaco, L. M. P., M. P. Marques, N. C. Madeira, C. M. VilaViçosa, and P. Mendes. 2011. Folklore and traditional ecological knowledge of geckos in Southern Portugal: implications for conservation and science. Journal of Ethnobiology and Ethnomedicine 7(26):9. http://dx.doi.org/10.1186/1746-4269-7-26

Davis, A., and K. Ruddle. 2010. Constructing confidence: rational skepticism and systematic enquiry in local ecological knowledge research. Ecological Applications 20(3):880-894. http://dx.doi. org/10.1890/09-0422.1

Dollo, M., G. V. Gopi, K. Teegalalli, and K. Mazmudar. 2010. Conservation of orange-bellied Himalayan squirrel Dremomys lokriah using a traditional knowledge system: case study from Arunachal Pradesh, India. Oryx 44:573-576. http://dx.doi. org/10.1017/S0030605310000785

Drew, J. A. 2005. Use of traditional ecological knowledge in marine conservation. Conservation Biology 19(4):1286-1293. http://dx.doi.org/10.1111/j.1523-1739.2005.00158.x

East, R. 1990. Antelopes: global survey and regional action plan. Part 3: West and Central Africa. IUCN, Gland, Switzerland. [online] URL: https://portals.iucn.org/library/node/8976

Ferguson, M. A. D., and F. Messier. 1997. Collection and analysis of traditional ecological knowledge about a population of Arctic tundra caribou. Arctic 50(1):17-28. http://dx.doi.org/10.14430/ arctic1087

Foale, S. 2006. The intersection of scientific and indigenous ecological knowledge in coastal Melanesia: implications for contemporary marine resource management. International Social Science Journal 58(187):129-137. http://dx.doi.org/10.1111/ j.1468-2451.2006.00607.x

Garibaldi, A., and N. Turner. 2004. Cultural keystone species: implications for ecological conservation and restoration. Ecology and Society 9(3):1. [online] URL: http://www.ecologyandsociety. org/vol9/iss3/art1/

Gaze, P., and R. Smith. 2009. A harvesting wananga on Titi Island: maintaining connections by rekindling a wildlife harvest. Journal of the Royal Society of New Zealand 39(4):193-196. http:// dx.doi.org/10.1080/03014220909510578

Ghana Statistical Service (GSS). 2005. 2000 population and housing data analysis report volume 1. Ghana Statistical Service, Accra, Ghana. [online] URL: http://www.statsghana.gov.gh/ nada/index.php/catalog/3 
Gilbert, M., C. Sokha, P. H. Joyner, R. L. Thomson, and C. Poole. 2012. Characterizing the trade of wild birds for merit release in Phnom Penh, Cambodia and associated risks to health and ecology. Biological Conservation 15:10-16. http://dx.doi. org/10.1016/j.biocon.2012.04.024

Gilchrist, G., M. Mallory, and F. Merkel. 2005. Can local ecological knowledge contribute to wildlife management? Case studies of migratory birds. Ecology and Society 10(1):20. [online] URL: http://www.ecologyandsociety.org/vol10/iss1/art20/

Golo, B. W.-K., and J. A. Yaro. 2013. Reclaiming stewardship in Ghana: religion and climate change. Nature and Culture 8 (3):282-300. http://dx.doi.org/10.3167/nc.2013.080304

Gratani, M., J. R. A. Butler, F. Royee, P. Valentine, D. Burrows, W. I. Canendo, and A. S. Anderson. 2011. Is validation of indigenous ecological knowledge a disrespectful process? A case study of traditional fishing poisons and invasive fish management from the Wet Tropics, Australia. Ecology and Society 16(3):25. http://dx.doi.org/10.5751/es-04249-160325

Houde, N. 2007. The six faces of traditional ecological knowledge: challenges and opportunities for Canadian co-management arrangements. Ecology and Society 12(2):34. [online] URL: http:// www.ecologyandsociety.org/vol12/iss2/art34/

Huntington, H. P. 2000. Using traditional ecological knowledge in science: methods and applications. Ecological Applications 10 (5):1270-1274. http://dx.doi.org/10.1890/1051-0761(2000)010[1270: utekis]2.0.co;2

Jiménez, J. E. 1996. The expatriation and current status of wild chinchillas Chinchilla lanigera and C. brevicaudata. Biological Conservation 77:1-6. http://dx.doi.org/10.1016/0006-3207(95) 00116-6

Johannes, R. E. 2002. The renaissance of community-based marine resource management in Oceania. Annual Review of Ecology and Systematics 33(1):317-340. http://dx.doi.org/10.1146/ annurev.ecolsys.33.010802.150524

Kideghesho, J. 2009. The potentials of traditional African cultural practices in mitigating overexploitation of wildlife species and habitat loss: experience of Tanzania. International Journal of Biodiversity Science and Management 5:83-94. http://dx.doi. org/10.1080/17451590903065579

Kingdon, J. 1982. East African mammals. Academic Press, London, UK.

Mcivor, A., and G. Pungetti. 2012. The conservation status of sacred species: a preliminary study. Pages 195-206 in G. Pungetti, G. Oviedo, and D. Hooke, editors. Sacred species and sites: advances in biocultural conservation. Cambridge University Press, Cambridge, UK. http://dx.doi.org/10.1017/cbo9781139030717.020

McNiven, I. J., and R. Feldman. 2003. Ritually orchestrated seascapes: hunting magic and dugong bone mounds in Torres Strait, NE Australia. Cambridge Archaeological Journal 13 (2):169-194. http://dx.doi.org/10.1017/s0959774303000118

Meijaard, E., K. Mengersen, D. Buchori, A. Nurcahyo, M. Ancrenaz, S. Wich, S. S. U. Atmoko, A. Tjiu, D. Prasetyo, Nardiyono, Y. Hadiprakarsa, L. Christy, J. Wells, G. Albar, and A. J. Marshall. 2011. Why don't we ask? A complementary method for assessing the status of great apes. PLoS ONE, 6(3): e18008. http://dx.doi.org/10.1371/journal.pone.0018008

Moller, H., F. Berkes, P. O. Lyver, and M. Kislalioglu. 2004. Combining science and traditional ecological knowledge: monitoring populations for co-management. Ecology and Society 9(3):2. [online] URL: http://www.ecologyandsociety.org/vol9/ iss $3 / \operatorname{art} 21$

Ormsby, A. 2012. Cultural and conservation values of sacred forests in Ghana. Pages 335-350 in G. Pungetti, G. Oviedo, and D. Hooke, editors. Sacred species and sites: advances in biocultural conservation. Cambridge University Press, Cambridge, UK. http://dx.doi.org/10.1017/cbo9781139030717.032

Parrinder, G. 1961. West African religion: a study of the beliefs and practices of Akan, Ewe, Yoruba, Ibo, and kindred peoples. Wipf and Stock, Eugene, Oregon.

Parry, L., and C. A. Peres. 2015. Evaluating the use of local ecological knowledge to monitor hunted tropical-forest wildlife over large spatial scales. Ecology and Society 20(3):15. http://dx. doi.org/10.5751/es-07601-200315

Pauly, D. 1995. Anecdotes and the shifting base-line syndrome of fisheries. Trends in Ecology and Evolution 10(10):430. [online] URL: http://www.webpages.uidaho.edu/envs501/downloads/Pauly $\%$ 201995.pdf

Pellier, A.-S., J. A. Wells, N. K. Abram, D. Gaveau, and E. Meijaard. 2014. Through the eyes of children: perceptions of environmental change in tropical forests. PLoS ONE 9(8): e103005. http://dx.doi.org/10.1371/journal.pone.0103005

Pungetti, G. 2012. Sacred species and sites: dichotomies, concepts and new directions in biocultural diversity conservation. Pages 13-27 in G. Pungetti, G. Oviedo, and D. Hooke, editors. Sacred species and sites: advances in biocultural conservation. Cambridge University Press, Cambridge, UK. http://dx.doi.org/10.1017/ cbo9781139030717.005

Rabinowitz, A., T. Myint, S. T. Khaing, and S. Rabinowitz. 1999. Description of the leaf deer (Muntiacus putaoensis), a new species of muntjac from northern Myanmar. Journal of Zoology 249:427-435. http://dx.doi.org/10.1111/j.1469-7998.1999.tb01212. $\underline{\mathrm{X}}$

Riley, E. P. 2010. The importance of human-macaque folklore for conservation in Lore Lindu National Park, Sulawesi, Indonesia. Oryx 44(2): 235-240. http://dx.doi.org/10.1017/ $\underline{\mathrm{s} 0030605309990925}$

Rowcliffe, J. M., R. Kays, C. Carbone and P. A. Jansen. 2013. Clarifying assumptions behind the estimation of animal density from camera trap rates. Journal of Wildlife Management 77 (5):876. http://dx.doi.org/10.1002/jwmg.533

Sammy, J. 2010. Exploring the sustainability of place: a case study of community-based nature tourism. Dissertation. University of Guelph, Guelph, Ontario, Canada.

Serra, G., M. Abdallah, A. Assaed, A. Abdallah, G. Al Qaim, T. Fayad, and D. Williamson. 2004. Discovery of a relict breeding colony of northern bald ibis Geronticus eremita in Syria. Oryx 38:106-108. http://dx.doi.org/10.1017/S003060530400016X 
Sheppard, D. J., A. Moehrenschlager, J. M. McPherson, and J. J. Mason. 2010. Ten years of adaptive community-governed conservation: evaluating biodiversity protection and poverty alleviation in a West African hippopotamus reserve. Environmental Conservation 37(3):270-282. http://dx.doi.org/10.1017/ $\underline{\text { s037689291000041x }}$

Simons, E. L., and D. M. Meyers. 2001. Folklore and beliefs about the Aye aye (Daubentonia madagascariensis). Lemur News 6:11-16.

Turvey, S. T., L. A. Barrett, Y. Hao, L. Zhang, X. Zhang, X. Wang, Y. Huang, K. Zhou, T. Hart, and D. Wang. 2010. Rapidly shifting baselines in Yangtze fishing communities and local memory of extinct species. Conservation Biology 24(3):778-787. http://dx.doi. org/10.1111/j.1523-1739.2009.01395.x

Turvey, S. T., C. Fernández-Secades, J. M. Nuñez-Miño, T. Hart, P. Martinez, J. L. Brocca, and R. P. Young. 2014. Is local ecological knowledge a useful conservation tool for small mammals in a Caribbean multicultural landscape? Biological Conservation 169:189-197. http://dx.doi.org/10.1016/j.biocon.2013.11.018

Turvey, S. T., C. L. Risley, J. E. Moore, L. A. Barrett, Y. Hao, X. Zhao, K. Zhou, and D. Wang. 2013. Can local ecological knowledge be used to assess status and extinction drivers in a threatened freshwater cetacean? Biological Conservation 157:352-360. http://dx.doi.org/10.1016/j.biocon.2012.07.016

Turvey, S. T., C. T. Trung, V. D. Quyet, H. V. Nhu, D. V. Thoai, V. C. A. Tuan, D. T. Hoa, K. Kacha, T. Sysomphone, S. Wallate, C. T. T. Hai, N. V. Thanh, and N. M. Wilkinson. 2015. Interviewbased sighting histories can inform regional conservation prioritization for highly threatened cryptic species. Journal of Applied Ecology 52(2):422-433. http://dx.doi.org/10.1111/1365-2664.12382

United Nations (UN). 1992. Convention on biological diversity. United Nations, Montreal, Quebec, Canada. [online] URL: https://www.cbd.int/convention/text/default.shtml

Walsh, F. J., P. V. Dobson, and J. C. Douglas. 2013. Anpernirrentye: a framework for enhanced application of indigenous ecological knowledge in natural resource management. Ecology and Society 18(3):18. http://dx.doi.org/10.5751/es-05501-180318

Willoughby, N., R. Grimble, W. Ellenbroek, E. Danso, and J. Amatekpor. 2001. The wise use of wetlands: identifying development options for Ghana's coastal Ramsar sites. Hydrobiologia 458:221-234. http://dx.doi.org/10.1023/A:1013158329107 


\section{Appendix 1}

\section{Education Campaign}

We here provide details about the education campaign that was implemented in Avu Lagoon communities. The education campaign occurred over a two year period and aimed to engage communities in conservation through education.

\section{Environmental Education Team}

In order to enable all of the citizens within the participating communities to become more involved and informed, a 10-member Environmental Education Team (EET) was established to educate communities on the conservation initiative. The purpose of the EET is to share knowledge about the community-owned project and to provide a forum for feedback and discussion.

To begin the process, Board Members were asked to recommend one or two persons from their various communities to be interviewed. In order to be selected for a position on the EET potential candidates were required to meet a specific set of qualifications. Candidates had to have completed Senior Secondary School or have equivalent qualifications, be able to translate English to Ewe and be interested in being trained as environmental educators to create awareness in the project communities. Interested persons were interviewed by the NCRC Field Officer and Project Advisor and a group of ten youth were hired. To give equal opportunity to the various communities, qualified representatives were selected from eight different communities.

The EET members were trained through a series of workshops facilitated by NCRC staff. EET members engaged in both 'classroom' or theory and practical learning (i.e. practicing the new knowledge acquired in front of a live audience) to prepare for leading community workshops. A presentation schedule was created to guide the EET in their activities. The schedule helped the communities to be informed ahead of the intended meeting and to get prepared to mobilize the population to actively engage in the process.

Important topics were prioritized for implementation at this early stage in the protected area's development. The EET facilitated three teaching modules in a 2-year awareness campaign. The module titles are as follows:

Module \#1: What is the Avu Lagoon Community Protected Area? Module \#2: Environmentally Friendly Farming and Fishing Facts Module \#3: Living with Wildlife

Workshops for Module \#1 "What is the Avu Lagoon Community-protected Area?" occurred from May to August 2008 in 14 communities. Community participation was variable with the smallest audience gathered at Bludo with just 25 participants and the largest audience gathered at Avuto with 208 members. The module was focused on creating awareness and outlined what a community-protected area is, why conservation is important and what the costs and benefits of the CPA might be for the communities. 
Community presentations for Module \#2 "Environmentally Friendly Farming and Fishing Practices" occurred from October 2008 to March 2009 in 14 communities. The largest audience was recorded at 144 members in Bleamezado and the smallest audience was 13 members who gathered at Bekpo. This module was designed to help community members improve farming and fishing practice. A major concern addressed during these workshops was the use of chemicals (pesticides) for farming and fishing. A total of 429 booklets entitled Farming and Fishing Facts were distributed over the duration of the program.

A total of eleven community workshops took place for Module \#3 "Living with Wildlife" between June and November 2009. The largest audience was recorded at 307 members in Bleamezado and the smallest audience size was 18 members who gathered at Gui. A total of 184 Living with Wildlife booklets were distributed over the period of the program. The purpose of these workshops was to demonstrate the importance of wildlife within the CPA. Topics for discussion were food chains, human wildlife conflict, the benefits of wildlife and how to live in harmony with wildlife.

The education campaign reached an estimated $10 \%$ of the population for Module 1, 7.3\% for Module 2 and $6.8 \%$ for Module 3 (Participants present at each workshop provided in Table A1). Throughout the campaign challenges were experienced when the team attempted to engage the community representatives around meeting times and dates. In several communities, appointments were cancelled and rescheduled, and in a few cases community meetings were not held. 
Table A1 Number of participants present and booklets distributed during EET workshops for Modules 1-3 (2008-2009).

\begin{tabular}{|l|l|l|l|l|l|}
\hline $\begin{array}{l}\text { Name of } \\
\text { Community }\end{array}$ & $\begin{array}{l}\text { Size of } \\
\text { Audience } \\
\text { Module \#1 }\end{array}$ & $\begin{array}{l}\text { Size of } \\
\text { Audience } \\
\text { Module \#2 }\end{array}$ & $\begin{array}{l}\text { Number of } \\
\text { Booklets } \\
\text { Distributed } \\
\text { Module \#2 }\end{array}$ & $\begin{array}{l}\text { Size of } \\
\text { Audience } \\
\text { Module \#3 }\end{array}$ & $\begin{array}{l}\text { Number of } \\
\text { Booklets } \\
\text { Distributed } \\
\text { Module \#3 }\end{array}$ \\
\hline Adutor & 47 & 73 & 57 & 32 & 17 \\
\hline Agbagorme & 65 & 99 & 35 & --- & --- \\
\hline Agbogbla & 65 & 126 & 65 & 50 & 23 \\
\hline Agorbledokui & 124 & 76 & 30 & --- & --- \\
\hline Avuto & 208 & 22 & 15 & 27 & 19 \\
\hline Bayive & 33 & 20 & 22 & 36 & 20 \\
\hline Bekpo & 36 & 13 & 15 & --- & --- \\
\hline Bleamazado & 62 & 144 & 52 & 307 & 20 \\
\hline Bludo & 25 & 15 & 12 & 20 & 11 \\
\hline Gui & 64 & --- & --- & 18 & 16 \\
\hline Suipe & --- & 35 & 35 & 22 & 21 \\
\hline Tosukpo & 65 & 33 & 23 & 37 & 20 \\
\hline Tsawoeme & 37 & 26 & 27 & 37 & 8 \\
\hline Wenu & 30 & 21 & 17 & 25 & 9 \\
\hline Xavi & 48 & 30 & 30 & --- & --- \\
\hline Totals & $\mathbf{9 0 9}$ & $\mathbf{7 3 3}$ & $\mathbf{4 2 9}$ & $\mathbf{6 1 1}$ & $\mathbf{1 8 4}$ \\
\hline
\end{tabular}




\section{Appendix 2}

\section{Interview Topics}

We here provide details on the questions or topics that guided each type of interview outlined in Table 1 of the main manuscript. Note that all but the hunter interviews were semi-structured, such that the order of questions was not fixed, and questions were adapted or omitted depending on the discussion that had already ensued. Overlap of questions or topics among interviews with different stakeholders allowed for cross-checking and clarification.

\section{Eye-witness interviews}

1. Could you describe what you remember happening at the time when you learned about the sitatunga?

2. Were people in the communities (hunters, chiefs, caretakers of shrines) open and willing to share when you visited and wanted to see the bones and skins?

3. What was your relationship with the community? Did you know anyone in the community? Did you know the chief?

4. Do you know if people were still actively hunting sitatunga at that time?

5. Did you know about the shrines at the time and the cultural significance of the sitatunga? And/or what do you know about that now?

6. Any further contributions to add.

\section{$\underline{\text { Board member interviews }}$}

1. What did you hope for/what were your expectations when the CPA started? Have those expectations been met?

2. Who or what organizations have helped in the formation of the CPA and what kind of help have they brought?

3. The Management Board was launched only recently, who made decisions about the natural resources (the Lagoon) before that?

4. Were the traditions and culture considered when the CPA was started?

5. What role do traditional leaders play now?

6. What can your traditions and culture teach other people about the protection of the lagoon and wildlife?

7. What have you learned from the traditions and culture of others to help you protect your resources? (forest, fish, wildlife, rivers etc)

8. What are the benefits of the CPA for your community?
a. Economic
b. Social-cultural
c. Environmental (access to resources, protection of medicinal plants, food plants, increase wildlife etc)


9. What are the costs or the negative effects of the CPA for your community?

a. Economic

b. Social-cultural

c. Environmental (access to resources, protection of medicinal plants, food plants, loss of farm land, hunting, fishing etc)

10. What are the challenges being faced by the Avu Lagoon Management Board?

11. What do you think should be done to address these challenges?

\section{$\underline{\text { Elder focus groups }}$}

1. Impacts of Akosombo Damn: effects on the environment, flood regimes, sitatunga, access or use of resources, hunting, fishing

2. Sitatunga hunting: has it stopped, when and why?

3. The importance of sitatunga for appeasing the gods

4. Alternative animals for sacrifice: wild or domestic, formerly what happened when sitatunga were not available, predominant species used in sacrifice today, any change in what is commonly sacrificed over time, reasons for such change

5. Past change in the number of maintenance of hunting shrines (since the time of respondents' grandfathers)

6. Future outlook for hunting shrines (what will respondents' grandchildren encounter?)

7. Purpose and physical appearance of hunting shrines: formerly and current, changes over time, reasons for change

\section{$\underline{\text { Shrine caretaker interviews }}$}

Topics covered with the caretakers of shrines within communities

1. Ownership and history of the shrine: who established it, when (relative to family generations or marked events in recent and longer-term history), and who looks after it

2. Purpose of the shrine: the circumstances under which the deity at this shrine is consulted, who can consult it, how this is done, and whether this has changed over time

3. Animal remains in the shrine: species, origin and spiritual significance

Topics covered with caretakers of forest groves and associated shrines

1. Ownership and history of the grove and the associated shrine: who looks after it, on whose behalf, and how long has the grove been protected (relative to family generations or marked events in recent and longer-term history)

2. Purpose of the shrine: the circumstances under which the deity at this shrine is consulted, who can consult it, how this is done, and whether this has changed over time

3. Size of the grove

4. Location and accessibility of the grove 
5. Restrictions regarding grove access and grove use: activities permitted, activities prohibited, who may enter, who should not, and under what circumstances, changes in any of the above

6. State of the grove: level of enforcement or adherence to restrictions

7. Ownership and state of other, nearby groves

\section{$\underline{\text { Hunter interviews }}$}

1. Preliminary mammal species list for Avu Lagoon (in Ewe and English),

2. Hunting practices and frequencies, uses of meat, and taboos on hunting

3. Sitatunga behavioural ecology information including times most frequently seen and problems between sitatunga and humans

4. Documentation of first hand encounters with sitatunga including time of encounter (year/month/time of day), number and sex of animals sighted, location of sighting, method(s) employed to spot the animal, and activity of animal during observation 